\title{
AGRONOMIC PERFORMANCE OF ERECT AND SEMI-ERECT COWPEA GENOTYPES IN THE NORTH OF MINAS GERAIS, BRAZIL ${ }^{1}$
}

\author{
JOÃO VÍCTOR SANTOS GUERRA ${ }^{2 *}$, ABNER JOSÉ DE CARVALHO ${ }^{2}$, JHONATA CANTUÁRIA MEDEIROS ${ }^{2}$, \\ ANDREY ANTUNES DE SOUZA², ORLANDO GONÇALVES BRITO ${ }^{3}$
}

\begin{abstract}
The objective of this work was to evaluate the agronomic performance of elite-strains of cowpea cultivars under the conditions of the north of Minas Gerais (MG), Brazil. Fifteen elite-strains and five erect and semi-erect cultivars of cowpea were evaluated in the 2014 and 2015 summer-fall crop seasons in Janaúba MG. A randomized block experimental design was used with four replications. Plant size, lodging and value of cultivation, pod length and grain yield were evaluated. The data of the two crops were subjected to individual and joint analysis of variance. The genotype-crop interactions significantly affected all studied variables. The strains MNC04-792F-146 and MNC04-792F-144 stood out as the most productive genotypes in both crops. The cultivars BRS Itaim and BRS Novaera presented adequate size and lodging characteristics for cultivation, and values of cultivation that meet commercial standards, thus representing good alternatives for the genotypes cultivated in the north of Minas Gerais.
\end{abstract}

Keywords: Vigna unguiculata. Value of cultivation. Yield.

\section{PERFORMANCE AGRONÔMICA DE GENÓTIPOS DE FEIJÃO-CAUPI ERETOS E SEMIERETOS NO NORTE DE MINAS GERAIS}

RESUMO - Objetivou-se com este trabalho avaliar a performance agronômica de linhagens-elite e cultivares de feijão-caupi, nas condições de cultivo do Norte de Minas Gerais. Foram avaliadas 15 linhagens-elite e cinco cultivares de feijão-caupi de portes ereto e semiereto, nas safras de verão-outono de 2014 e 2015, em Janaúba, MG. O delineamento experimental foi o de blocos casualizados, com quatro repetições. Foram avaliados o porte da planta, o grau de acamamento e o valor de cultivo, o comprimento da vagem e o rendimento de grãos. Os dados obtidos foram submetidos a análises de variância individuais e conjunta, envolvendo as duas safras de cultivo. Verificou-se efeito significativo para a interação entre genótipos e safras para todas as variáveis estudadas. As linhagens MNC04-792F-146 e MNC04-792F-144 destacaram-se por estarem entre os genótipos mais produtivos nas duas safras avaliadas. As cultivares BRS Itaim e BRS Novaera apresentaram simultaneamente características de porte e acamamento adequadas para o cultivo, além de obterem valor de cultivo compatível com o padrão comercial, representando boas alternativas de cultivo no Norte de Minas Gerais.

Palavras-chave: Vigna unguiculata. Valor de cultivo e uso. Produtividade.

\footnotetext{
*Corresponding author

${ }^{1}$ Received for publication in 08/14/2016; accepted in 11/17/2016.

Paper approved from IV CONAC 2016.

${ }^{2}$ Department of Agrarian Sciences, Universidade Estadual de Montes Claros, Janaúba, MG, Brazil; joaoifnmg@yahoo.com.br, abjocar@yahoo.com.br,jhonata1002009@hotmail.com, andreyantunes1@hotmail.com.

${ }^{3}$ Department of Agrarian Sciences, Universidade Federal dos Vales do Jequitinhonha e Mucuri, Diamantina, MG, Brazil; orlandocefet@yahoo.com.br.
} 


\section{INTRODUCTION}

Cowpea (Vigna unguiculata (L.) Walp.) is a widely-cultivated legume in the semi-arid regions of Africa, Brazil and United States (ROCHA et al., 2009). The great genetic variability of this species allows to use it for various purposes and cultivate it in various production systems (ANDRADE et al., 2010). Cowpea has great socioeconomic importance in the Northeast region of Brazil, since it is one of the staple foods for the low-income population of this region (LIMA et al., 2011). However, the cultivation of this legume has expanding to more technified areas of the country due to the increased market demand.

The north of Minas Gerais, Brazil, is a traditional region of cowpea production and consumption, however, the production in this region is limited by the low level of technology employed and cultivars used, which are recommended based on studies in other regions of the country.

The estimated Brazilian production of cowpea for the 2015-2016 crop is $390,100 \mathrm{Mg}$, with average yield of $373 \mathrm{~kg} \mathrm{ha}^{-1}$ (CONAB, 2016). However, the current yields are not consistent with the crop productive potential, since grain yields higher than $4,000 \mathrm{~kg} \mathrm{ha}{ }^{-1}$ were found under experimental conditions (SILVA, 2014). Therefore, improvements of morphoagronomic characteristics of cowpea, especially those related to grain yield, must be emphasized to reach higher yields (TEIXEIRA et al., 2007).

In addition, the improvement of characteristics related to the plant architecture, aiming to develop more erect cultivars (MATOS FILHO et al., 2009) with good commercial quality is essential, due to the trend of use of more technified production systems, which generate the need for cultivars with suitable size and architecture characteristics to a greater densification and mechanization of the crop, including harvesting (BEZERRA et al., 2008).

Cowpea cultivars are cropped in different regions of the country, thus, cultivars adapted to a certain cultivation condition may not perform satisfactorily in other environmental conditions (TEODORO et al., 2015). These different performances are due to the cowpea intrinsic genetic, physiological and morphological characteristics, which cause different responses of cultivars to local edaphoclimatic conditions (SANTOS et al., 2009).

The different responses of genotypes to growing environments are usually evaluated through the interaction genotype $\mathrm{x}$ environment (TEODORO et al., 2015). According to Santos, Araújo and
Menezes (2000), the effects of this interaction may be due to environmental conditions, soil fertility, producers' technological knowledge, management system used, which change the genotype performance.

In this context, it is important to carry out regional studies, aiming to select superior cowpea genotypes and to recommend cultivars appropriate to local growing conditions and consumer markets. Thus, the objective of this work was to evaluate the agronomic performance of elite-strains of erect and semi-erect cowpea cultivars under the conditions of the north of Minas Gerais, Brazil.

\section{MATERIAL AND METHODS}

The experiments were conducted in the Experimental Farm of the Universidade Estadual de Montes Claros, Janaúba, Minas Gerais (MG) $\left(15^{\circ} 47^{\prime} 50^{\prime \prime} \mathrm{S}, 43^{\circ} 18^{\prime} 31^{\prime \prime} \mathrm{W}\right.$ and altitude of $\left.516 \mathrm{~m}\right)$, in the 2014 and 2015 summer-fall crop seasons. The treatments consisted of 20 erect and semi-erect cowpea genotypes, 15 elite-strains and 5 cultivars, all developed by the Embrapa Meio-Norte Cowpea Breeding Program in the evaluation of value of cultivation and use (VCU) of the group erect and semi-erect. The genotypes evaluated, their origins/parents and commercial subclasses are described in Table 1.

A randomized block experimental design was used, with four replications. The plots consisted of four $5-\mathrm{m}$ rows spaced $0.5 \mathrm{~m}$ apart, with about ten plants per meter. The two central rows of each plot were considered for evaluation, discarding $0.5 \mathrm{~m}$ from each end of the rows, resulting in an evaluation area of $4.0 \mathrm{~m}^{2}$ per plot.

The soil of the experimental area was prepared with one plowing and two harrowing at pre-planting. The soil was then furrowed and fertilized using a fertilizer-sowing machine. The seeds were sowed in March of each year, using manual seeders. The soil was fertilized following the recommendations of Melo, Cardoso and Salviano (2005) for cowpea, based on the soil chemical analysis, consisting of $20 \mathrm{~kg} \mathrm{ha}^{-1}$ of $\mathrm{P}_{2} \mathrm{O}_{5}$ and $\mathrm{K}_{2} \mathrm{O}$ at planting and $20 \mathrm{~kg} \mathrm{ha}^{-1}$ of $\mathrm{N}$ as sidedressing, 25 days after planting. The weeds were manually removed at 20 days after emergence. A complementary irrigation was used from planting to grain filling through a conventional spraying system with a total water depth of approximately $350 \mathrm{~mm}$ and three days of applications. The temperature and precipitation during the experimental period are presented in Figure 1. 
Table 1. Origins/parents and commercial subclasses of the erect and semi-erect cowpea genotypes used for the evaluations of value of cultivation and use.

\begin{tabular}{lcc}
\hline \multicolumn{1}{c}{ Genotype } & Origin/Parent & $\begin{array}{c}\text { Commercial } \\
\text { Subclass }\end{array}$ \\
\hline MNC04-762F-3 & TE96-282-22G x (Te96-282-22G X Vita7) & BL \\
MNC04-762F-9 & TE96-282-22G x (Te96-282-22G x Vita 7) & BL \\
MNC04-769F-30 & CE-315 x TE97-304G-12 & ML \\
MNC04-769F-48 & CE-315 x TE97-304G-12 & ML \\
MNC04-792F-146 & CE-315 x TE97-304G-12 & ML \\
MNC04-769F-62 & (TE97-309G-24 x TE96-406-2E-28-2) x TE97-309G-24 & SV \\
MNC04-782F-104 & MNC00-553D-8-1-2-3 x TV x 5058-09C & ML \\
MNC04-792F-143 & MNC00-553D-8-1-2-3 x TV x 5058-09C & SV \\
MNC04-792F-144 & MNC00-553D-8-1-2-3 x TV x 5058-09C & ML \\
MNC04-792F-148 & MNC99-518G-2 x IT92KD-279-3 & ML \\
MNC04-795F-153 & MNC99-518G-2 x IT92KD-279-3 & SV \\
MNC04-795F-154 & MNC99-518G-2 x IT92KD-279-3 & ML \\
MNC04-795F-155 & MNC99-518G-2 x IT92KD-279-3 & ML \\
MNC04-795F-159 & MNC99-518G-2 x IT92KD-279-3 & BR \\
MNC04-795F-168 & IT85F-2687 x TE87-98-8G & BL \\
BRS Guariba & TE96-282-22G x IT87D-611-3 & BL \\
BRS Tumucumaque & TE97-404-1F x TE97-404-3F & BR \\
BRS Novaera & MNC01-625E-10-1-2-5 x MNC99-544D-101-2-2 & FR \\
BRS Itaim & TE93-210-13F x TE96-282-22G & BL \\
BRS Cauamé
\end{tabular}

$\mathrm{BL}=$ Branco Liso; $\mathrm{BR}=$ Branco Rugoso; FR = Fradinho; $\mathrm{ML}=$ Mulato; SV = Sempre Verde. Source: Embrapa MeioNorte (Experiment worksheet, 2016).

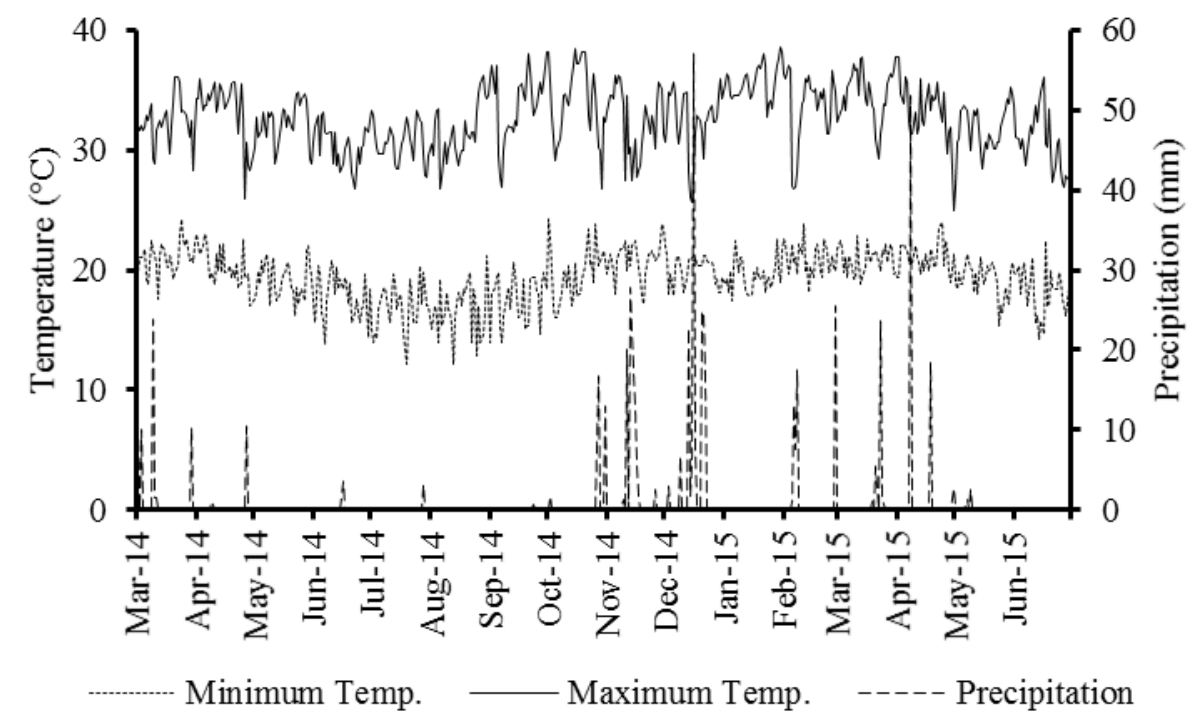

Figure 1. Daily minimum and maximum temperature $\left({ }^{\circ} \mathrm{C}\right)$ and precipitation $(\mathrm{mm})$ during the experimental period. (Source: INMET, 2016).

The plant size (PS), lodging degree (LD) and value of cultivation (VC) of the studied genotypes were evaluated at physiologic maturity of the plants, according to a visual scale of grades, as described in Table 2. Then, the plots were harvested to evaluate the average pod length (PL), measuring the length of
20 pods, randomly selected at harvest; and the average grain yield (GY), weighing all the grains harvested in the evaluation area of each plot and correcting the values to a $13 \%$ of humidity and transforming them to $\mathrm{kg} \mathrm{ha}^{-1}$. 
Table 2. Scale of grades used to classify the plant size, lodging degree and value of cultivation of cowpea plants.

\begin{tabular}{|c|c|c|c|}
\hline Grade & Plant size & Lodging degree & Value of cultivation \\
\hline 1 & Erect & No lodged plants & $\begin{array}{c}\text { Strain/cultivar without characteristics suitable for commercial } \\
\text { cultivation }\end{array}$ \\
\hline 2 & Semi-erect & $\begin{array}{l}1 \text { to } 5 \% \text { of lodged } \\
\text { plants }\end{array}$ & $\begin{array}{l}\text { Strain/cultivar with few characteristics suitable for commercial } \\
\text { cultivation }\end{array}$ \\
\hline 3 & Semi-prostrate & $\begin{array}{l}6 \text { to } 10 \% \text { of lodged } \\
\text { plants }\end{array}$ & $\begin{array}{l}\text { Strain/cultivar with most of the characteristics suitable for } \\
\text { commercial cultivation }\end{array}$ \\
\hline 4 & Prostrate & $\begin{array}{l}11 \text { to } 20 \% \text { of lodged } \\
\text { plants }\end{array}$ & $\begin{array}{c}\text { Strain/cultivar with all characteristics suitable for commercial } \\
\text { cultivation }\end{array}$ \\
\hline 5 & - & $\begin{array}{l}\text { Over } 20 \% \text { of lodged } \\
\text { plants }\end{array}$ & $\begin{array}{c}\text { Strain/cultivar with excellent characteristics for commercial } \\
\text { cultivation }\end{array}$ \\
\hline
\end{tabular}

Source: Adapted from the Embrapa Meio-Norte (Experiment worksheet, 2016).

The data of the two crops were subjected to individual and joint analysis of variance. The differences between the means of the genotypes were evaluated by the Scott-Knott test, at 5\% of significance, while the crops were compared by the $\mathrm{F}$ test, at $5 \%$ of significance.

\section{RESULTS AND DISCUSSION}

According to the joint analysis of variance, the interaction of genotypes with crops significantly affected all variables evaluated. The plant size of the genotypes in the 2014 crop were similar.
The cultivars BRS Cauamé and BRS Itaim, followed by the strains MNC04-762F-9, MNC04-795F-159, MNC04-795F-155 and cultivar BRS Novaera had the lowest grades of plant size in the 2015 crop, therefore, these genotypes were the most erect. All genotypes in the 2014 crop had lower or equal grades to those in the 2015 crop (Table 3 ). This result may be related to the climatic conditions of each crop, since the 2014 crop had slightly lower temperatures and precipitation than the 2015 crop (Figure 1). However, the differences were little and all genotypes presented plant size grades lower than 2.0 in both crops (Table 3), denoting their classification as semi-erect or erect (Table 2).

Table 3. Average plant size, lodging degree and pod length of 20 erect and semi-erect cowpea genotypes, evaluated in the summer-fall crop season of 2014 and 2015.

\begin{tabular}{lcccccc}
\hline \multirow{2}{*}{ Genotype } & \multicolumn{2}{c}{ Plant size } & \multicolumn{2}{c}{ Lodging degree } & \multicolumn{2}{c}{ Pod length } \\
\cline { 2 - 7 } & 2014 & 2015 & 2014 & 2015 & 2014 & 2015 \\
\hline MNC04-762F-3 & $1.38 \mathrm{Aa}$ & $1.63 \mathrm{Ba}$ & $3.50 \mathrm{Aa}$ & $3.33 \mathrm{Ba}$ & $18.62 \mathrm{Ab}$ & $21.06 \mathrm{Aa}$ \\
MNC04-762F-9 & $1.25 \mathrm{Aa}$ & $1.44 \mathrm{Ca}$ & $3.67 \mathrm{Aa}$ & $3.00 \mathrm{Ba}$ & $19.87 \mathrm{Aa}$ & $19.97 \mathrm{Ba}$ \\
MNC04-762F-30 & $1.31 \mathrm{Ab}$ & $1.69 \mathrm{Ba}$ & $4.33 \mathrm{Aa}$ & $4.00 \mathrm{Aa}$ & $18.36 \mathrm{Aa}$ & $19.14 \mathrm{Ba}$ \\
MNC04-769F-48 & $1.06 \mathrm{Ab}$ & $1.94 \mathrm{Aa}$ & $3.00 \mathrm{Ab}$ & $5.00 \mathrm{Aa}$ & $18.14 \mathrm{Ba}$ & $19.39 \mathrm{Ba}$ \\
MNC04-792F-146 & $1.19 \mathrm{Ab}$ & $1.94 \mathrm{Aa}$ & $2.50 \mathrm{Bb}$ & $5.00 \mathrm{Aa}$ & $18.85 \mathrm{Aa}$ & $19.07 \mathrm{Ba}$ \\
MNC04-769F-62 & $1.38 \mathrm{Ab}$ & $1.88 \mathrm{Aa}$ & $3.00 \mathrm{Ab}$ & $4.50 \mathrm{Aa}$ & $17.82 \mathrm{Ba}$ & $18.39 \mathrm{Ca}$ \\
MNC04-782F-104 & $1.25 \mathrm{Ab}$ & $1.94 \mathrm{Aa}$ & $3.25 \mathrm{Ab}$ & $5.00 \mathrm{Aa}$ & $19.94 \mathrm{Aa}$ & $20.51 \mathrm{Aa}$ \\
MNC04-792F-143 & $1.50 \mathrm{Aa}$ & $1.75 \mathrm{Ba}$ & $1.50 \mathrm{Bb}$ & $4.50 \mathrm{Aa}$ & $19.38 \mathrm{Aa}$ & $19.59 \mathrm{Ba}$ \\
MNC04-792F-144 & $1.56 \mathrm{Aa}$ & $1.75 \mathrm{Ba}$ & $3.67 \mathrm{Aa}$ & $4.50 \mathrm{Aa}$ & $18.95 \mathrm{Aa}$ & $18.72 \mathrm{Ba}$ \\
MNC04-792F-148 & $1.25 \mathrm{Ab}$ & $1.69 \mathrm{Ba}$ & $3.50 \mathrm{Aa}$ & $3.33 \mathrm{Ba}$ & $19.39 \mathrm{Aa}$ & $19.37 \mathrm{Ba}$ \\
MNC04-795F-153 & $1.44 \mathrm{Ab}$ & $1.88 \mathrm{Aa}$ & $4.00 \mathrm{Aa}$ & $4.00 \mathrm{Aa}$ & $19.22 \mathrm{Aa}$ & $19.85 \mathrm{Ba}$ \\
MNC04-795F-154 & $1.44 \mathrm{Aa}$ & $1.63 \mathrm{Ba}$ & $3.33 \mathrm{Aa}$ & $3.25 \mathrm{Ba}$ & $20.51 \mathrm{Aa}$ & $20.55 \mathrm{Aa}$ \\
MNC04-795F-155 & $1.38 \mathrm{Aa}$ & $1.50 \mathrm{Ca}$ & $2.75 \mathrm{Aa}$ & $3.33 \mathrm{Ba}$ & $17.98 \mathrm{Bb}$ & $19.89 \mathrm{Ba}$ \\
MNC04-795F-159 & $1.31 \mathrm{Aa}$ & $1.56 \mathrm{Ca}$ & $2.75 \mathrm{Aa}$ & $3.00 \mathrm{Ba}$ & $17.57 \mathrm{Bb}$ & $19.50 \mathrm{Ba}$ \\
MNC04-795F-168 & $1.31 \mathrm{Ab}$ & $1.69 \mathrm{Ba}$ & $3.33 \mathrm{Aa}$ & $2.75 \mathrm{Ba}$ & $17.80 \mathrm{Ba}$ & $17.51 \mathrm{Ca}$ \\
BRS Guariba & $1.31 \mathrm{Ab}$ & $1.88 \mathrm{Aa}$ & $2.00 \mathrm{Bb}$ & $3.50 \mathrm{Ba}$ & $16.73 \mathrm{Bb}$ & $19.47 \mathrm{Ba}$ \\
BRS Tumucumaque & $1.38 \mathrm{Aa}$ & $1.63 \mathrm{Ba}$ & $2.75 \mathrm{Ab}$ & $3.75 \mathrm{Ba}$ & $19.11 \mathrm{Ab}$ & $21.79 \mathrm{Aa}$ \\
BRS Novaera & $1.38 \mathrm{Aa}$ & $1.50 \mathrm{Ca}$ & $1.67 \mathrm{Ba}$ & $1.50 \mathrm{Ca}$ & $14.79 \mathrm{Cb}$ & $16.41 \mathrm{Ca}$ \\
BRS Itaim & $1.38 \mathrm{Aa}$ & $1.25 \mathrm{Da}$ & $1.25 \mathrm{Ba}$ & $1.00 \mathrm{Ca}$ & $15.92 \mathrm{Ca}$ & $17.25 \mathrm{Ca}$ \\
BRS Cauamé & $1.25 \mathrm{Aa}$ & $1.13 \mathrm{Da}$ & $3.33 \mathrm{Aa}$ & $1.50 \mathrm{Cb}$ & $20.14 \mathrm{Aa}$ & $17.29 \mathrm{Cb}$ \\
\hline Means & & & & &
\end{tabular}

Means followed by the same uppercase letter in the column comparing the genotypes and lowercase letters in the row comparing crops were similar by the Scott-Knott test and F test at $5 \%$ of significance, respectively. 
The lodging degree of the genotypes was significantly different in both crops. The lodging degree grades ranged from 1.25 to 4.33 in the 2014 crop, with the genotypes MNC04-792F-146, MNC04-792F-143, BRS Guariba, BRS Novaera and BRS Itaim presenting the lowest values; and from 1.00 to 5.00 in the 2015 crop, with the cultivars BRS Novaera, BRS Itaim and BRS Cauamé presenting the lowest values. Thus, the cultivars BRS Novaera and BRS Itaim stood out among the genotypes with the lowest lodging rates in both crops (Table 3). Machado et al. (2008) characterize 22 erect cowpea genotypes regarding their precocity, yield and architecture, under irrigated conditions in Teresina, Piauí, Brazil, and found similar lodging degrees, with values ranging from 1.0 to 4.75 . A low lodging degree of the plants is desired for erect cowpea genotypes, so that they can be cultivated in more technified production systems, with intense use of mechanization.

Similar to the results of plant size, the highest lodging grades were found in the 2015 crop. This result is related to the climatic conditions during the experimental period, since during the 2015 crop occurred higher temperatures and precipitation (Figure 1), which may have resulted in a greater growth of the plants, modifying their architecture and making them more susceptible to lodging. According to Rocha et al. (2009), characteristics of the cowpea plant architecture, such as length of hypocotyl, internodes, main and secondary branches and peduncle, and their growth habit, can result in more or less lodging of plants.

Regarding the pod length, the genotypes of both crops presented significant differences. The pod length ranged from 14.79 to $20.51 \mathrm{~cm}$ in the 2014 crop, with average of $18.45 \mathrm{~cm}$, and the genotypes MNC04-762F-3, MNC04-762F-9, MNC04-762F-30, MNC04-792F-146, MNC04-782F-104, MNC04792F-143, MNC04-792F-144, MNC04-792F-148, MNC04-795F-153, MNC04-795F-154, BRS Tumucumaque and BRS Cauamé presenting the highest values. The pod length values ranged from 16.41 to $21.79 \mathrm{~cm}$ in the $2015 \mathrm{crop}$, with average of $19.24 \mathrm{~cm}$, and the genotypes MNC04-762F-3, MNC04-782F-104, MNC04-795F-154 and BRS Tumucumaque presenting the highest values (Table 3)

According to Freire Filho (2011), cowpea cultivars released from 1991 to 2010 had an average length of $18 \mathrm{~cm}$. Other authors (MIRANDA et al., 1996; SILVA; NEVES, 2011) considered pods with length above $20 \mathrm{~cm}$ as standard. However, the maximum pod length has not yet been established, and a minimum length of $18 \mathrm{~cm}$ was considered as the standard value in this study. Thus, only the genotypes MNC04-769F-62, MNC04-795F-155, MNC04-795F-159, MNC04-795F-168, BRS Guariba, BRS Novaera and BRS Itaim, in the 2014 crop, and genotypes MNC04-795F-168, BRS Novaera, BRS Itaim and BRS Cauamé, in the 2015 crop, presented pods smaller than the commercial standard.

According to Silva and Neves (2011), plants with smaller pods and smaller number of grains and thus, lighter pods, are preferred in semi-mechanized and mechanized crops, since they reduce the stalk bending and breaking. According to these authors, these characteristics reduce the pod contact with the soil and losses by pod and grain rotting. On the other hand, small pods can reduce the plant yield, since they produce fewer grains and, depending on the magnitude of this reduction, the plant could not compensate by increasing the number of pods. This characteristic must be evaluated together with other variables, especially grain yield, since the use of plants with smaller pods may not reduce the yield due to the compensatory capacity of the plants (phenotypic plasticity), as reported by Freire Filho, Lima and Ribeiro (2005) and Santos et al. (2011).

The value of cultivation of the genotypes presented significant differences in both crops. The genotypes MNC04-762F-9, MNC04-792F-146, MNC04-792F-143, MNC04-792F-144, BRS Guariba, BRS Tumucumaque, BRS Novaera and BRS Itaim presented the highest values of cultivation in the 2014 crop. The genotypes MNC04-762F-9, MNC04-762F-30, MNC04-795F-154, MNC04-795F -155, MNC04-795F-159, MNC04-795F-168, BRS Tumucumaque, BRS Novaera, BRS Itaim and BRS Cauamé presented the highest values of cultivation in the 2015 crop (Table 4).

The value of cultivation is determined based on evaluations of the plant's general appearance, vigor, architecture, load, pod characteristics, grain quality and phytosanitary aspect (SILVA; NEVES, 2011). New cowpea cultivars must have value of cultivation of at least 3.00 to meet the requirements of the markets, thus meaning that the material has most of the characteristics suitable for commercial cultivation (Table 2). Therefore, the strain MNC04762F-9 and the cultivars BRS Novaera, BRS Tumucumaque and BRS Itaim stood out in this study, presenting values of cultivation equal to or greater than 3.00 in both crops (Table 4). 
Table 4. Average value of cultivation and grain yield of 20 erect and semi-erect cowpea genotypes, evaluated in the summer-fall crop season of 2014 and 2015.

\begin{tabular}{|c|c|c|c|c|}
\hline \multirow{2}{*}{ Genotype } & \multicolumn{2}{|c|}{ Value of cultivation } & \multicolumn{2}{|c|}{ Grain yield $\left(\mathrm{kg} \mathrm{ha}^{-1}\right)$} \\
\hline & 2014 & 2015 & 2014 & 2015 \\
\hline MNC04-762F-3 & $2.50 \mathrm{Ba}$ & $2.38 \mathrm{Ba}$ & $1,278.44 \mathrm{Ba}$ & $1,652.76 \mathrm{Ba}$ \\
\hline MNC04-762F-9 & $3.00 \mathrm{Aa}$ & $3.00 \mathrm{Aa}$ & $1,653.25 \mathrm{Ba}$ & $1,478.88 \mathrm{Ba}$ \\
\hline $\mathrm{MNC} 04-762 \mathrm{~F}-30$ & $2.67 \mathrm{Ba}$ & $2.63 \mathrm{Aa}$ & $2,590.47 \mathrm{Aa}$ & $1,853.43 \mathrm{Bb}$ \\
\hline MNC04-769F-48 & $2.75 \mathrm{Ba}$ & $1.88 \mathrm{Ba}$ & $1,570.31 \mathrm{Ba}$ & $2,021.15 \mathrm{Ba}$ \\
\hline MNC04-792F-146 & $3.00 \mathrm{Aa}$ & $1.63 \mathrm{Bb}$ & $2,309.40 \mathrm{Aa}$ & $2,352.30 \mathrm{Aa}$ \\
\hline MNC04-769F-62 & $2.75 \mathrm{Ba}$ & $1.75 \mathrm{Ba}$ & $1,610.90 \mathrm{Bb}$ & $2,192.01 \mathrm{Aa}$ \\
\hline MNC04-782F-104 & $2.25 \mathrm{Ba}$ & $1.50 \mathrm{Ba}$ & $2,002.92 \mathrm{Aa}$ & $1,970.98 \mathrm{Ba}$ \\
\hline MNC04-792F-143 & $3.50 \mathrm{Aa}$ & $2.25 \mathrm{Bb}$ & $1,889.34 \mathrm{Aa}$ & $1,712.44 \mathrm{Ba}$ \\
\hline MNC04-792F-144 & $3.25 \mathrm{Aa}$ & $2.00 \mathrm{Bb}$ & $1,801.72 \mathrm{Ab}$ & $2,645.71 \mathrm{Aa}$ \\
\hline MNC04-792F-148 & $2.25 \mathrm{Ba}$ & $2.38 \mathrm{Ba}$ & $551.58 \mathrm{Cb}$ & $1,469.54 \mathrm{Ba}$ \\
\hline MNC04-795F-153 & $2.25 \mathrm{Ba}$ & $2.00 \mathrm{Ba}$ & $1,875.49 \mathrm{Aa}$ & $1,906.31 \mathrm{Ba}$ \\
\hline MNC04-795F-154 & $2.25 \mathrm{Ba}$ & $3.00 \mathrm{Aa}$ & $1,398.56 \mathrm{Bb}$ & $2,366.61 \mathrm{Aa}$ \\
\hline MNC04-795F-155 & $2.75 \mathrm{Ba}$ & $3.00 \mathrm{Aa}$ & $1,549.88 \mathrm{Ba}$ & $2,026.62 \mathrm{Ba}$ \\
\hline MNC04-795F-159 & $2.50 \mathrm{Ba}$ & $2.88 \mathrm{Aa}$ & $1,431.94 \mathrm{Bb}$ & 2,969.72 Aa \\
\hline MNC04-795F-168 & $2.25 \mathrm{Ba}$ & $2.75 \mathrm{Aa}$ & $1,465.87 \mathrm{Bb}$ & 2,282.91 Aa \\
\hline BRS Guariba & $4.00 \mathrm{Aa}$ & $2.25 \mathrm{Bb}$ & $2,126.14 \mathrm{Aa}$ & $1.440,38 \mathrm{Bb}$ \\
\hline BRS Tumucumaque & $3.25 \mathrm{Aa}$ & $3.25 \mathrm{Aa}$ & $1,332.92 \mathrm{Ba}$ & 1.,787.98 Ba \\
\hline BRS Novaera & $3.00 \mathrm{Aa}$ & $3.50 \mathrm{Aa}$ & 1.609.24 Ba & $2,050.05 \mathrm{Ba}$ \\
\hline BRS Itaim & $3.75 \mathrm{Aa}$ & $3.50 \mathrm{Aa}$ & $1,623.50 \mathrm{Bb}$ & $2,230.77 \mathrm{Aa}$ \\
\hline BRS Cauamé & $2.25 \mathrm{Bb}$ & $3.75 \mathrm{Aa}$ & $1,489.89 \mathrm{Ba}$ & $1,969.62 \mathrm{Ba}$ \\
\hline
\end{tabular}

Means followed by the same uppercase letter in the column comparing the genotypes and lowercase letters in the row comparing crops were similar by the Scott-Knott test and F test at 5\% significance, respectively.

The genotypes affected the grain yield in both crops. The grain yields of the 2014 crop ranged from 551.58 to $2,590.47 \mathrm{~kg} \mathrm{ha}^{-1}$, with the strains MNC04-792F-144, MNC04-795F-153, MNC04792F-143, MNC04-782F-104, MNC04-792F-146, MNC04-762F-30 and the cultivar BRS Guariba as the most productive, presenting grain yields above $1,801 \mathrm{~kg} \mathrm{ha}^{-1}$. The grain yields of the 2015 crop ranged from $1,440.38$ to $2,969.72 \mathrm{~kg} \mathrm{ha}^{-1}$, with the strains MNC04-795F-154, MNC04-795F-159, MNC04-795F-168, MNC04-769F-62, MNC04-792F -144 , MNC04-792F-146 and the cultivar BRS Itaim as the most productive, presenting grain yields above 2,192 $\mathrm{kg} \mathrm{ha}^{-1}$. Thus, the strains MNC04-792F-146 and MNC04-792F-144 stand out from the other genotypes as the only ones among those most productive in both crops (Table 4).

The average yield found in this work, 1658.09 $\mathrm{kg} \mathrm{ha}^{-1}$ in the 2014 and $2019.01 \mathrm{~kg} \mathrm{ha}^{-1}$ in the 2015 crop, were higher than the national average yield of cowpea, which is approximately $373 \mathrm{~kg} \mathrm{ha}{ }^{-1}$ (CONAB, 2016), and also higher than those found in other researches (PASSOS et al., 2007; ROCHA et al., 2007; TEIXEIRA et al., 2007; MACHADO et al., 2008; MATOS FILHO et al., 2009; VALADARES et al., 2010; SILVA; NEVES, 2011).

All genotypes evaluated presented satisfactory yields under the conditions of the north of Minas Gerais, thus, the decision-making to recommend a genotype must consider the evaluations of yield with other characteristics. The cultivars BRS Itaim and BRS Novaera stood out in this study, presenting favorable size and lodging for mechanized cultivation; the strain MNC04-762F-9 and the cultivars BRS Novaera, BRS Tumucumaque and BRS Itaim stood out with high values of cultivation; and the strains MNC04-792F-146 and MNC04-792F-144 stood out with good yield in both crops.

\section{CONCLUSIONS}

The cultivars BRS Itaim and BRS Novaera stood out in the north of Minas Gerais, with the best agronomic performance, presenting satisfactory yields and good characteristics of size, lodging and value of cultivation. The strains MNC04-792F-146 
and MNC04-792F-144 also stood out, presenting good yields in both crops.

\section{ACKNOWLEDGEMENTS}

The authors thank the FAPEMIG, Capes, CNPq, Embrapa Mio-Norte and UNIMONTES for granting scholarships and supporting this research project.

\section{REFERENCES}

ANDRADE, F. N. et al. Estimativas de parâmetros genéticos em genótipos de feijão-caupi avaliados para feijão fresco. Revista Ciência Agronômica, Fortaleza, v. 41, n. 2, p. 253-258, 2010.

BEZERRA, A. A. C. et al. Morfologia e produção de grãos em linhagens modernas de feijão-caupi submetidas a diferentes densidades populacionais. Revista de Biologia e Ciências da Terra, Aracaju, v. 8, n. 1, p. $85-93,2008$.

\section{COMPANHIA}

\section{NACIONAL}

DE ABASTECIMENTO - CONAB. Observatório Agrícola: acompanhamento da safra brasileira de grãos - Safra 2015/16 - Décimo levantamento, v. 3, n. 10. Brasília, 2016, 179 p.

FREIRE FILHO, F. R. Feijão-caupi no Brasil: produção, melhoramento genético, avanços e desafios. 1. ed. Teresina, PI: Embrapa Meio-Norte, 2011.84 p.

FREIRE FILHO, F. R.; LIMA, J. A. A.; RIBEIRO, V. Q. Feijão-caupi: avanços tecnológicos. 1. ed. Brasília, DF: Embrapa Informação Tecnológica, 2005. 519 p.

\section{INSTITUTO}

NACIONAL

DE METEOROlogiA - INMET. Banco de Dados Meteorológicos para Ensino e Pesquisa. Disponível em: <http://www.inmet.gov.br/portal/>. Acesso em: 11 jan. 2016.

LIMA, J. R. S. et al. Balanço de energia e evapotranspiração de feijão caupi sob condições de sequeiro. Revista Ciência Agronômica, Fortaleza, v. 42 , n. 1 , p. $65-74,2011$.

MACHADO, C. F. et al. Identificação de genótipos de feijão-caupi quanto à precocidade, arquitetura da planta e produtividade de grãos. Revista Ciência Agronômica, Fortaleza, v. 39, n. 1, p. 114-123, 2008.

MATOS FILHO, C. H. A. et. al. Potencial produtivo de progênies de feijão-caupi com arquitetura ereta de planta. Ciência Rural, Santa Maria, v. 39, n. 2, p. 348-354, 2009.

MELO, F. B.; CARDOSO, M. J.; SALVIANO, A. A. C. Fertilidade do solo e adubação. In: FREIRE FILHO, F. R.; LIMA, J. A. A.; RIBEIRO, V. Q. (Eds.). Feijão-caupi: avanços tecnológicos. Brasília: Embrapa Informação Tecnológica, 2005. cap. 6, p. 230-242.

MIRANDA, P. et al. Comportamento de cultivares de Vigna unguiculata (L) Walp., nos sistemas solteiro e consorciado. IV - tipos ereto e semi-ereto. Pesquisa Agropecuária Pernambucana, Recife, v. 9, Sup., p. 95-105, 1996.

PASSOS, A. R. et al. Divergência genética em feijão-caupi. Bragantia, Campinas, v. 66, n. 4, p. 579-586, 2007.

ROCHA, M. M. et al. Adaptabilidade e estabilidade produtiva de genótipos de feijão-caupi de porte semi-ereto na Região Nordeste do Brasil. Pesquisa Agropecuária Brasileira, Brasília, v. 42, n. 9, p. 1283-1289, 2007.

ROCHA, M. M. et al. Controle genético do comprimento do pedúnculo em feijão-caupi. Pesquisa Agropecuária Brasileira, Brasília, v. 44, n. 3, p. 270-275, 2009.

SANTOS, C. A. F.; ARAÚJO, F. P.; MENEZES, E. A. Comportamento produtivo de caupi em regimes irrigado e de sequeiro em Petrolina e Juazeiro. Pesquisa Agropecuária Brasileira, Brasília, v. 35, n. 11, p. 2229-2234, 2000.

SANTOS, E. R. et al. Crescimento e teores de pigmentos foliares em feijão-caupi cultivado sob dois ambientes de luminosidade. Revista Caatinga, Mossoró, v. 24, n. 4, p. 14-19, 2011.

SANTOS, J. F. et al. Novas variedades de caupi para a microrregião do Brejo Paraibano. Revista Tecnologia e Ciência Agropecuária, João Pessoa, v. 3, n. 3, p. 07-12, 2009.

SILVA, J. A. L.; NEVES, J. A. Componentes de produção e suas correlações em genótipos de feijão-caupi em cultivo de sequeiro e irrigado. Revista Ciência Agronômica, Fortaleza, v. 42, n. 3, p. 702-713, 2011.

SILVA, J. D. L. Seleção simultânea para desenvolvimento de linhagens de feijão-caupi de porte ereto e do tipo fradinho. 2014. $73 \mathrm{f}$. Dissertação (Mestrado em Genética e Melhoramento) - Universidade Federal do Piauí, Teresina, 2014. 
TEIXEIRA, N. F. P. et al. Produção, componentes de produção e suas inter-relações em genótipos de feijão-caupi [Vigna unguiculata (L.) Walp.] de porte ereto. Revista Ceres, Viçosa, v. 54, n. 314, p. 374-382, 2007.

TEODORO, P. E. et al. Perspectiva bayesiana na seleção de genótipos de feijão-caupi em ensaios de valor de cultivo e uso. Pesquisa Agropecuária Brasileira, Brasília, v. 50, n. 10, p. 878-885, 2015.

VALADARES, R. N. et al. Adaptabilidade e estabilidade fenotípica em genótipos de feijão-caupi (Vigna unguiculata (L.) Walp.) de porte ereto/ semiereto nas mesorregiões Leste e Sul Maranhense. Agropecuária Científica no Semi-Árido, Patos, v. 6, n. 2, p. 21-27, 2010. 